\author{
Збірник наукових праць. Серія: Галузеве машинобудування, будівництво \\ Academic journal. Series: Industrial Machine Building, Civil Engineering \\ http://journals.pntu.edu.ua/znp \\ https://doi.org/10.26906/znp.2018.51.1311
}

UDC 629.119

\title{
Determination of the pressure in the cylinder of the automotive internal combustion engine by the installation of tensommetric sensors
}

\author{
Korobko Bogdan ${ }^{1}$, Vasyliev Oleksiy ${ }^{2}$, Rohozin Ivan ${ }^{3}$, Vasyliev Ievgen ${ }^{4}$ \\ ${ }^{1}$ Poltava National Technical Yuri Kondratyuk University https://orcid.org/0000-0002-9086-3904 \\ ${ }_{2}^{2}$ Poltava National Technical Yuri Kondratyuk University https://orcid.org/0000-0002-9914-5482 \\ ${ }^{3}$ Poltava National Technical Yuri Kondratyuk University https://orcid.org/0000-0002-9052-4806 \\ ${ }^{4}$ Poltava National Technical Yuri Kondratyuk University https://orcid.org/0000-0001-5133-3989 \\ *Corresponding author: a.s.vasiliev.76@gmail.com
}

The analysis of well-known methods of displaying and their cost has made it possible to conclude that the methods of direct and indirect displaying have a number of serious shortcomings. Therefore, the diagnostic method for the condition of the internal combustion engine according to the value of gas pressure in the cylinders of the engine has been proposed. This method allows determining its indicator ratios, assessing the engine's health of the ICE, the regulator (control) performance, efficiency and environmental cleanliness. This article describes the general principle of operation of the device and components of the process of measurement and processing of the obtained data. The authors of the article provided the connection diagram and substantiated the efficiency of the proposed method for obtaining information on internal cylinder processes. The results of the performed calculations indicate the suitability of the proposed calculation method for the simulation of internal cylinder processes inside internal combustion engines, including the modern ones.

Keywords: internal combustion engine, indicator diagram, diagnostics, gas pressure, cylinder-piston group, stud, stretching

\section{Визначення тиску в циліндрі двигуна внутрішнього згоряння автомобіля шляхом установлення тензометричних датчиків}

\author{
Коробко Б.О. ${ }^{1}$, Васильєв О.С. ${ }^{2 *}$, Рогозін І.А. ${ }^{3}$, Васильєв С.А. ${ }^{4}$ \\ 1, 2, 3,4 Полтавський національний технічний університет імені Юрія Кондратюка \\ *Адреса для листування: a.s.vasiliev.76@gmail.com
}

\begin{abstract}
Виконано аналіз відомих способів відображення та їх вартості, це дозволило зробити висновок, що методи прямого і непрямого відображення мають ряд серйозних недоліків. Запропоновано методику діагностування стану двигуна внутрішнього згоряння за значенням тиску газів у циліндрах двигуна. Визначено, що тиск газів у циліндрах двигуна $\epsilon$ найбільш інформативним діагностичним параметром, що характеризує стан його поршневої частини. Обробка індикаторних діаграм дозволяє отримати відомості про якість робочих процесів досліджуваного двигуна, встановити значення його індикаторних показників, оцінити технічний стан двигуна внутрішнього згоряння, якість регулювання, економічність, шумові та вібраційні показники й екологічну чистоту. Зазначено, що реалізація методу непрямого відображення полягає в тому, що під гайку або болт кріплення головки блока циліндрів поміщають датчик тиску, який являє собою сталеву шайбу із закріпленими на ній тензорезисторами. Зусилля, що виникають від дії сил тиску газів у циліндрі двигуна, передаються через головку блока циліндрів шпилькам або болтам кріплення головки блока циліндрів до самого блока. При цьому датчик тиску сприймає ті ж самі зусилля, перетворюючи їх на електричний сигнал. Таке рішення істотно спрощує пристрій датчика і робить його конструкцію універсальною. Наведено описання принципу роботи пристрою та складових процесу вимірювання й обробки отриманих даних. Подано схему підключення та обгрунтовано працездатність запропонованого способу отримання інформації про внутрішньоциліндрові процеси на прикладі реальних вимірювань і обробки отриманих даних. 3'ясовано, що результати виконаних розрахункових досліджень свідчать про придатність запропонованої методики розрахунку для моделювання внутрішньоциліндрових процесів двигунів внутрішнього згоряння, в тому числі й сучасних.
\end{abstract}

Ключові слова: двигун внутрішнього згоряння, індикаторна діаграма, діагностування, тиск газів, циліндропоршнева група, шпилька, розтягнення 
Introduction. The major vehicle component part, which accounts for the largest number of failures, is the internal combustion engine (ICE). The reliability of engines operation depends not only on their design, manufacturing technology, service conditions of cars, but to a large extent on the organization and the quality of their service. The perfection of any repair technique and any method of servicing is determined by the extent to which it provides the interaction between the objectively existing process of changing the technical condition of the object and the process of its technical operation. The traditional routinepreventive method of maintenance and repair, based on the performance of certain preventive maintenance through pre-scheduled intervals of time or work, regardless of the system conditions and parts status, provides weak interaction between these processes. Closer relationship between them is provided by the methods of maintenance and repair of the condition $[1,2]$. The basic principle of the methods of servicing and repairing as required is the principle of preventing the failure of the car systems and their individual most important units and parts while ensuring their maximum possible replacement life $[1,3]$. The methods of servicing and repairing as required provide for continuous or periodic control and measurement of parameters that determine the technical state of functional systems and functional units, that is, the implementation of continuous or periodic diagnostics of these objects [4].

The development of the ICE design, as well as the means of measuring and processing of the received information, requires continuous improvement of the existing diagnostic methods and the development of new, more advanced methods based on the use of the latest means of obtaining information about the technical state of the engines $[5,6]$.

Actual scientific researches and issues analysis. The analysis of various methods of ICE diagnosis and the practical experience of their use allow us to conclude that the existing methods have a large number of deficiencies, and for correct diagnosing of the ICE's condition it is necessary to use the combination of diagnostic methods [1, 7]. This circumstance requires the improvement of the existing methods (for modern ICE at least the modernization of the existing methods is necessary) and the development of new, more advanced and informative methods for obtaining information on the technical condition of ICEs that realize the possibility to monitor diagnostic parameters.

The gas pressure in the engine cylinders is the most informative diagnostic parameter [8, 9]. The processing of indicator diagrams allows you to get information about the course of the work processes of the diagnosed engines, to determine their ratios, to evaluate the technical state of the ICE, the quality of their regulation, efficiency and environmental cleanliness [10].
Selection of previously unsettled parts of the general problem. The analysis of well-known methods of displaying has made it possible to conclude that the methods of direct displaying have high cost and do not provide the necessary accuracy of the obtained data, in addition, their application for automotive engines is practically impossible because they do not have indicator cocks. Famous methods of indirect pressure measurement in ICE cylinders also have a number of disadvantages $[2,8]$, as a result of which they have not received mass distribution, and most of them are used as separate experimental works with limited precision and rather narrow scope of use. Very few methods, both direct and indirect, allow continuous monitoring of pressure in ICE cylinders $[9,10]$ necessary to obtain operational information about changes in its condition, timely response to emerging malfunctions by performing appropriate maintenance operations, which is the most important condition for predictive maintenance.

Setting objectives. The above mentioned circumstances make it necessary to develop new methods and means of displaying engines, while focusing on the development of methods and means of indirect displaying.

The main material and the results. The proposed method of indirect display of internal combustion piston engines is based on the measurement of the voltage acting in the elements of connection of body parts (studs, bolts), connecting the cylinder caps (head of the cylinder block) and the engine block. The choice of coupling elements as a measuring object is based on the fact that they perceive only the forces of gas pressure and, thus, allow indirect displaying of the engine characteristics. The calculation scheme of coupling elements of base members is presented in Fig. 1. In the non-operating state of the ICE, the power studs are loaded with the force of pretightening (the minimum force strains the stud).

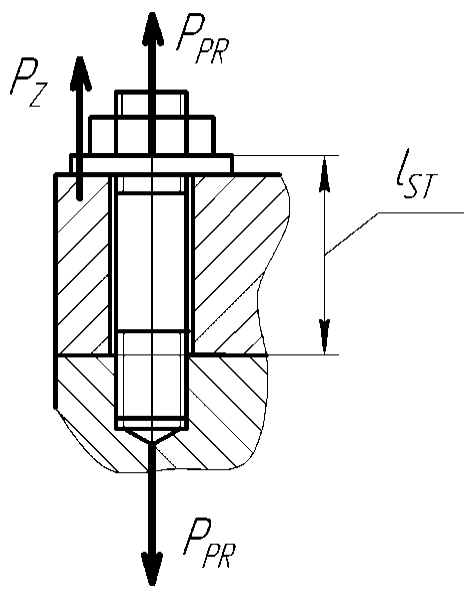

Figure 1 - Analytical model of joint members of nonrotational parts:

$P_{P R}$ - force of preliminary tightening of hold-down studs; $P_{Z}$ - the force that stretches the stud under the influence of the gas pressure; $l_{S T}$ - the ffective length of the stud 
$P_{P R} \approx m(1-\chi) P_{Z \max }^{\prime}, \mathrm{MN}$,

where $m$ - the tightening factor of the stud;

$\chi$ - coefficient of the main load of the threaded fastening;

$P^{\prime}{ }_{\text {max }}$ - force of gas pressure during combustion, which falls on one stud, $\mathrm{MN}$.

Under the influence of the force of the previous tightening, the stretching of the stud and the compression of the connecting parts takes place. At the same time, the stud is lengthened by the value $\lambda_{\text {STmin }}$

$\lambda_{S T \text { min }}=\frac{l_{S T} \cdot P_{P R}}{E \cdot F_{0}}, \mathrm{~m}$,

where $l_{S T}$ - the effective length of the stud, m;

$E$ - module of elasticity of a stud's material, $\mathrm{MPa}$;

$F_{0}$ - the area of the cross-section of the stud's plug, $\mathrm{m}^{2}$.

When the engine works, the pressure force of gases at burning causes additional stretching of the stud and head and compression of the head, the stud will be influenced by the power $P_{Z}$ :

$P_{Z}=P_{P R}+\chi P_{\text {Zmax }}^{\prime}, \mathrm{MN}$,

Under the influence of the force $P_{Z}$ the stud is lengthened by the value $\lambda_{S T \text { max }}$ :

$\lambda_{S T \text { max }}=\frac{l_{S T} \cdot P_{Z}}{E \cdot F_{0}}, \mathrm{~m}$,

The implementation of the indirect displaying method is the following: a pressure sensor, which is a steel washer with resistive-strain sensors, fixed on it, is placed under a screw or a hold-down bolt. Efforts arising from the action of the forces of gas pressure in the engine cylinder are transmitted through the cylinder head component to the studs or bolts of the cylinder head components to the block itself. In this case, the pressure sensor takes the same efforts, turning them into an electrical signal.

This solution greatly simplifies the sensor device and makes its design a versatile one. An example of a pressure sensor is shown in Fig. 2

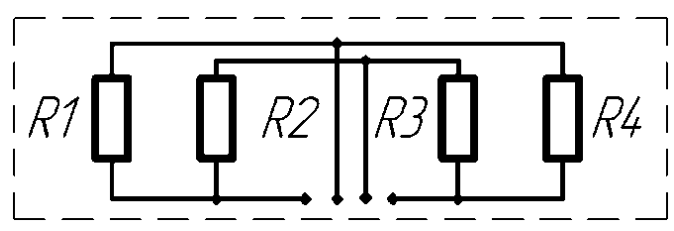

Figure 2 - The developed pressure sensor for the implementation of the indirect displaying method

There are four resistive-strain sensors, installed on the steel washer, that form a complete measuring circuit. Resistive-strain sensors R1 and R3 are set up for the perception of axial deformations; resistivestrain sensors R2 and R4 are used for thermocompensation.

Under the influence of the pressure change in the engine cylinder, the steel washer is compressed and stretched, being in the zone of elastic deformation, in this case resistive-strain sensors deform along with it, also changing their resistance. The signal from resistive-strain sensors, proportionally to the pressure in the ICE cylinder, with the help of the measuring circuit is converted into voltage, the value of which through the amplifier and the ADC is recorded by the computer, where it is further processed and analyzed. The following engines were chosen as the objects of research: engine GAZ-560; engine GAZ-5601; engine VAZ-2111.

In order to substantiate the efficiency of the proposed method of obtaining information on internal cylinder processes, the authors of the article have made the calculation of elongation of cylinder cover attachment studs (engines GAZ-560 and GAZ-5601), block bolts (VAZ-2111 engine) and compression of washes under them under the influence of forces from the previous tightening and gas pressure in the ICE cylinder. The results of the calculations show that the stretching of the cylinder cover studs (bolts) of the cylinder cap (block heads), as well as the compression of the washers underneath them while the engine is operating, are in the range available for registration by resistive-strain sensors. In particular, for the selected objects of investigation, the difference between the extension of the stud (bolt) with the maximum tensile strength and elongation at the force of the preliminary tightening is from 1 to 20 microns; the difference between the compression of the washer at maximum compressive strength and the compression with the force of the previous tightening is from 0.02 to 0.80 microns. Naturally, the most qualitative indirect indicator diagram can be achieved during the installation of resistive-strain sensors on the body of the cylinder cap mounting stud (or cylinder head bolt). However, in this case, the following problems arise: firstly, it is technologically difficult to install a resistive-strain sensor and to arrange the transmission of a signal from it, and secondly, the resistive-strain sensor is mounted on an unscrewed stud (bolt) of the cylinder cover (head of cylinder block), and in this case, the stud, together with the glued resistive-strain sensor, will be loaded with the force of pre-tightening $P_{P R}$. This force will stretch the stud and a resistivestrain sensor up to the value, that may exceed the permissible deformation of the resistive-strain sensor. In addition, when the engine is warmed, due to the thermal deformation of the parts, the load on the studs will increase. Thus, the main studies were related to the measurement of the stresses in the washers under the nuts of the studs of cylinder head fastener groups to the engine block (engines GAZ-560 and GAZ-5601) and in washers under the bolts of the cylinder head components (VAZ-2111 engine).

The general measuring scheme of the method of indirect displaying is presented in Fig. 3. Resistivestrain sensors 2 , installed on the washer 3 , compressed with a nut 1 of the stud 5 in the cylinder head fastener group 4 to the engine block 6 are connected to the 
measuring circuit. The signal from the measuring circuit is amplified in the amplifier 14 with a gain of 100 or 1000 , and, through an analog-to-digital converter 15 , is transmitted to the computer 16 , where its processing is carried out.

During tests on engines GAZ-560 and GAZ-5601 simultaneously with the registration of the indirect indicator diagram a direct dispaying was carried out using the GT-20 sensor of the company Autronica and the diagnostic complex K-748. The signal from the proximity sensor 9 (see Fig. 3) was recorded in parallel with the signal from the resistive-strain sensor 2 . In this case, the indicative diagrams taken with the GT-20 sensor, were considered as reference ones, and the diagrams, taken by the method of indirect displaying, were compared with them and their accuracy was estimated. The VAZ-2111 engine eliminates direct displaying, which in turn complicates the acquisition of absolute values of pressure in the cylinder, therefore the signal, registered from the resistive-strain sensor 2, proportional to the pressure in the cylinder, was considered as relative.

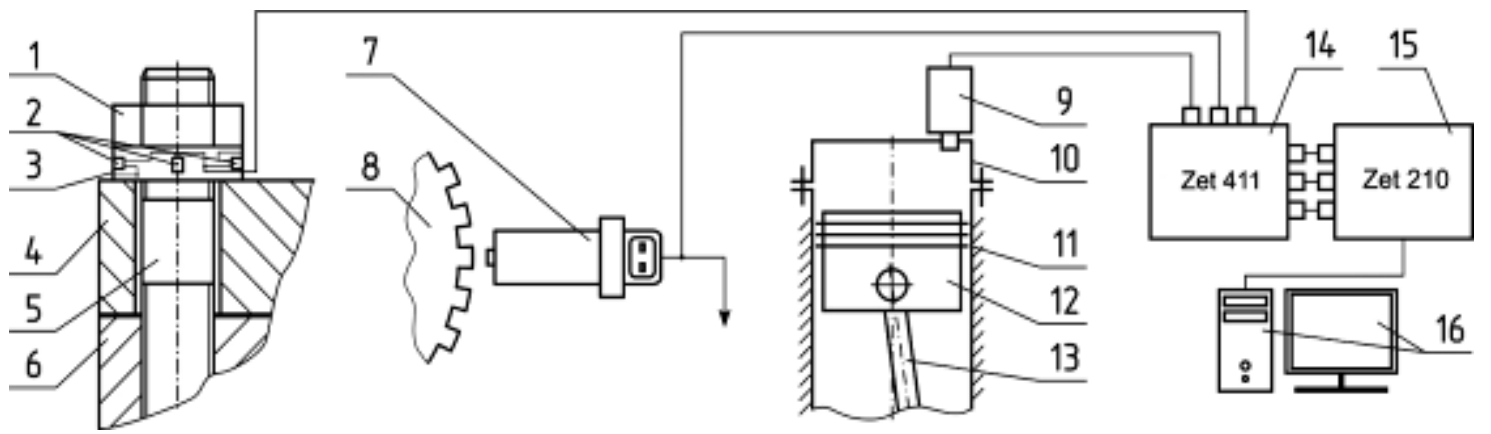

Figure 3 - The overall measurement scheme of the indirect displaying method:

1 - nut for attaching the cylinder head fastener group to the engine block; 2 - resistive-strain sensors;

3 - Washer under the nut of the the cylinder head fastener group to the engine block;

4, 10 - cylinder cover; 5 - attachment stud for cylinder head fastener group to the engine block;

6,11 - engine block; 7 - position sensor of the crankshaft; 8 - toothed crown of the crankshaft pulley;

9 - direct displaying sensor; 12 - piston; 13 - connecting rod;

14 - signal amplifier; 15 - analog-digital converter; 16 - computer

The measurements on the engine GAZ-560 were carried out in four modes: in idle run, at the load of 14,26 and $36 \mathrm{~kW}$. The measurements on the engine GAZ-5601 were conducted in three modes: idle run, with a load of 42 and $70 \mathrm{~kW}$. The measurements on the VAZ-2111 engine were conducted in idle run.

An important point in measuring the pressure in the ICE cylinders is to determine the position of the UDP in the diagram between the compression stroke and the expansion stroke. For the engines GAZ-560 and GAZ-5601 to determine the UDP at each mode of inspection, the fuel supply was switched off in the diagnostic cylinder and there was recorded compression-expansion pressure without the combustion process. According to the received diagram, the upper dead point was determined; then this diagram was superimposed on the pressure diagram with the combustion process (with the maximum coincidence of the polytrop of compression) and the moment of the UDP was determined. For the VAZ-2111 engine, in parallel with the indirect displaying, a signal from the normal inductive position sensor of the crankshaft 7 (see Fig. 3) was recorded to determine the upper dead point between the compression stroke and the expansion stroke.

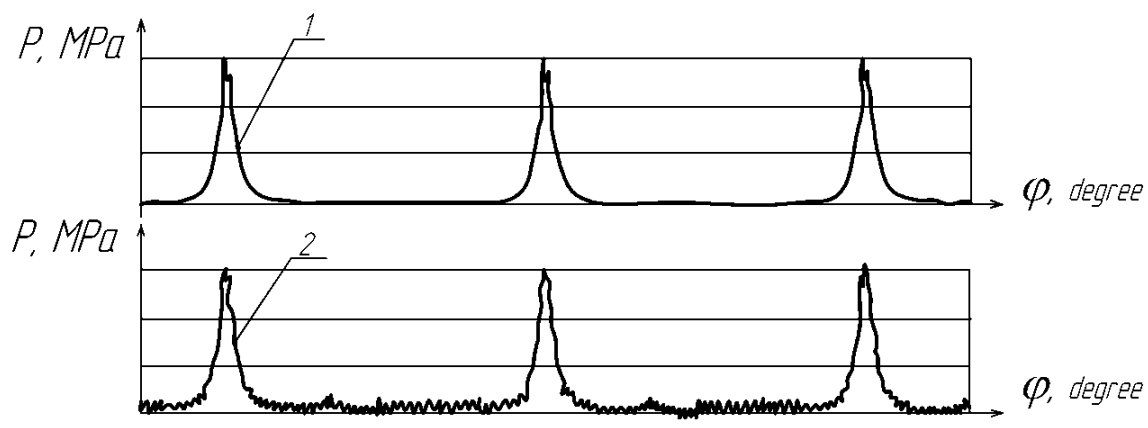

Figure 4 - Indicator diagrams of the engine GAZ-560:

1 - direct displaying; 2 - indirect displaying; three consecutive loops; idle run; $n=630 \mathrm{rpm}$; sampling rate of $20 \mathrm{kHz}$; signal without processing 


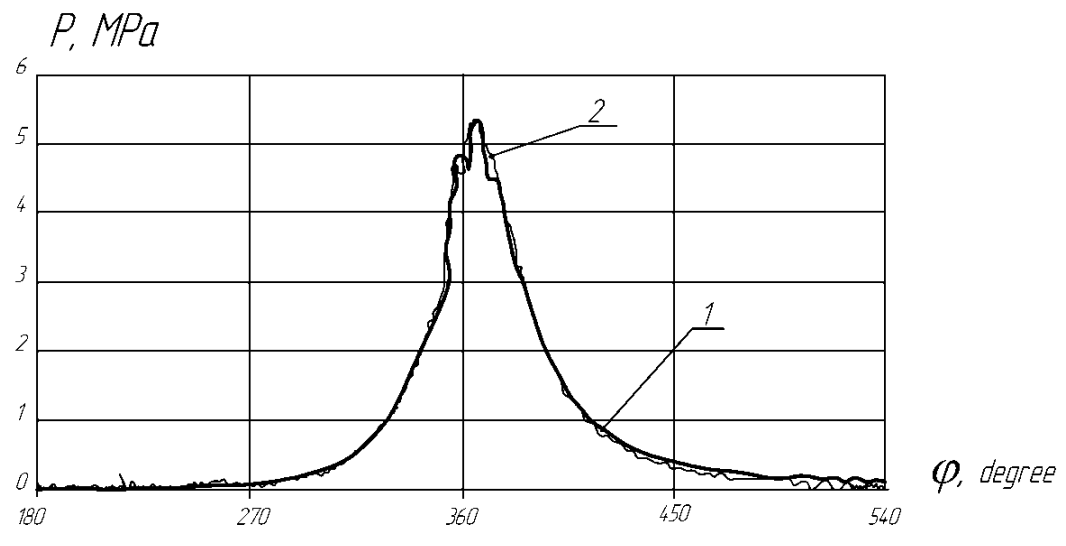

Figure 5 - Indicator diagrams of the engine GAZ-560:

1 - direct displaying; 2 - indirect displaying; load $36 \mathrm{~kW}$; $\mathrm{n}=582 \mathrm{rpm}$; average for 24 cycles

We will consider the results of the studies, obtained by the method of indirect displaying, on the example of the engine GAZ-560. In Fig. 4 there are shown indicator motor diagrams GAZ-560, obtained by direct 1 and indirect 2 displaying on idle run $(n=630$ rev / $\mathrm{min}$ ); on Fig. 5 there are shown average 24-cycle indicator motor diagrams GAZ-560 obtained by methods of direct 1 and indirect 2 displaying, while working under the load of $36 \mathrm{~kW}(\mathrm{n}=582 \mathrm{rpm})$.

Conclusion. The gas pressure in the engine cylinders is the most informative diagnostic parameter that characterizes the condition of its piston part. The processing of indicator diagrams allows you to get information about the quality of the work processes of the engine under investigation, to determine the value of its indicator ratios, to assess the regulator performance, efficiency and environmental cleanliness. The analysis of well- known methods of displaying and their cost has made it possible to conclude that the methods of direct and indirect displaying have a number of serious shortcomings that do not allow them to be used in practice. And, thus, there is a need to develop new methods and means of displaying engines.

\section{References}

1. Малышев, В.С., Бабошин, А.А. \& Корегин, А.Ю. (2009). Диагностирование двигателей транспортных средств с использованием методов косвенного индицирования. Автотранспортное предприятие, 2, 48-50.

2. Бабошин, А.А. \& Малышев, В.С. (2009). Анализ методов измерения давления в цилиндрах ДВС и обоснование необходимости разработки методов косвенного индицирования. Автотранспортное предприятие, 9 , 42-44.

3. Citron, S., O'Higgins, J., Chen, L. (1989). Cylinder by Cylinder Engine Pressure and Pressure Torque Waveform Determination Utilizing Speed Fluctuations. SAE Technical Paper, 890486. doi:10.4271/890486.
4. Lapuerta M., Armas, O. \& Hernández, J.J. (1999). Diagnosis of DI Diesel combustion from in-cylinder pressure signal by estimation of mean thermodynamic properties of the gas. Applied Thermal Engineering, 19(5), 513-529. doi:10.1016/S1359-4311(98)00075-1.

5. Brown, T.S. \& Neill W.S. (1992). Determination of Engine Cylinder Pressures from Crankshaft Speed Fluctuations. Journal of Engines, 101(3), 771-779. www.jstor.org/stable/44611250.

6. Payri, F., Olmeda, P., Guardiola, C. \& Martín, J. (2011). Adaptive determination of cut-off frequencies for filtering the in-cylinder pressure in diesel engines combustion analysis. Applied Thermal Engineering, 31(14-15, 2869-2876. doi:10.1016/j.applthermaleng.2011.05.012.

7. Isaev, A. \& Shchelkunov, A. (2008). Low frequency hydrophone calibration with using tensometric pressure sensor. The Journal of the Acoustical Society of America, 123(5), 1880-1882. doi:10.1121/1.2933907.

8. Бабошин, А.А. (2012). Результаты исследования метода косвенного индицирования поршневых двигателей внутреннего сгорания. Автотранспортное предприятие, 8, 42-46.

9. Scafati, F.T., Lavorgna, M., Mancaruso, E. \& Vaglieco, B. (2018). Use of in-Cylinder Pressure and Learning Circuits for Engine Modeling and Control. Nonlinear Systems and Circuits in Internal Combustion Engines, 5, 55-71. doi:10.1007/978-3-319-67140-6 5.

10. Svete, A., Bajsić, I. \& Kutin, J. (2018). Investigation of polytropic corrections for the piston-in-cylinder primary standard used in dynamic calibrations of pressure sensors. Sensors and Actuators A: Physical, 274, 262-271. doi:10.1016/j.sna.2018.03.019. 